\title{
To Assess the Frequency of Health-Related Problems Due to Excessive Usage of Mobile Phones in Medical Students
}

\author{
Sumera Nawaz Qabulio, Fasiha Sohail, Muhammad Fahad Zakir*, Iqbal Hussain, Nael Alavi and Sania Maqbool \\ Medicine Department, Ziauddin University and Hospital, Pakistan
}

Submission: June 18, 2018; Published: July 17, 2018

*Corresponding author: Muhammad Fahad Zakir, post graduate trainee of medicine department, Ziauddin University and Hospital, Pakistan, Tel: 92-333-2324002; Email: fahad_bawani@hotmail.com

\begin{abstract}
Review of Literature: The cell phone usage expanding worldwide and it consequences for the heath of human because of its radiation, electromagnetic radiation in the cell phone is excessively perilous and its range is around $450-2100 \mathrm{MHz}$ of the microwave range. Other information correspondence systems like computerized system creates a similar damage on human wellbeing in view of its radiation, now days it's an image marker for interpersonal organization examined in connection to it.
\end{abstract}

Method and Material:

Study Design: It's a Retro prospective survey based study done in private and government sector of hospital in Karachi.

Data Entry: Data entry was done by using SPSS 22 version.

Duration of Study: It was a 6month study starting date from 1 Dec 2016 b to 1 June 2017.

Sample Size: we enrolled around 410 all medical students house officers post graduates and consultants after proper consent, initially sample of 500 peoples were given question are out of which 410 filled question are were returned.

Inclusion Criteria: 1.M.B.B.S students, 2 Students, 3 House officer, 4 Post Graduates. 5. Consultant.

Exclusion Criteria: Non medical professions, 2 any disease ear ache, depression.

Result: In our study we enrolled 410 peoples both male and female from both sectors private and government sectors. Number of people enrolled in our cases our Medical students 246 and post graduates 83,42 house officers and others (consultants, supervisors). The highest usage was in the medical students.

Conclusion: Highest percentage of data enrolled were medical students with most frequently use for internet followed by messages and then calling, and most frequent symptoms were headache and disturbed sleep.

Keywords: Mobile phone; Cell phone; Depression; Headache; Hazards of phone

\section{Introduction}

The cell phone usage expanding worldwide and it consequences for the heath of human because of its radiation The quantity of cell phone is expanding overall this ought to be the enthusiasm of subject now a days1. Around 7.4 billion individuals are being subscribed all through around the world [1]. The electromagnetic radiation in the cell phone is excessively perilous and its range is around $450-2100 \mathrm{MHz}$ of the microwave range. Other information correspondence systems like computerized system creates a similar damage on human wellbeing in view of its radiation, now a days it's an image marker for interpersonal organization examined in connection to it. Including the likelihood of a diminishing shame about dysfunctional behavior, enhanced screening for maladjustment, and expanded help-chasing practices [2-4]. Another part of presentation is ergonomics. Musculoskeletal manifestations because of serious messaging on a cell phone have been accounted for [5], and methods utilized for content entering have been examined regarding creating musculoskeletal indications [6]. Not with standing, our viewpoint is overwhelmingly psychosocial.

In light of the past reviews, we needed to concentrate on a few parts of cell phone presentation other than negligible 
amount of utilization. For instance, requests on being accessible or rechargeable, paying little heed to time and space, could be contended to be a stressor independent of real recurrence of utilization. Another key determinant might be the degree to which a man really sees there particular availability as unpleasant. Besides, availability infers the likelihood to be aggravated at painfully inconvenient times, even at evening time. Having one's rest intruded on more than once can effectly affect recuperation and wellbeing. In a review among Finnish youths, escalated cell phone utilize was connected to poor saw wellbeing among young ladies, both specifically and through poor rest and waking-time tiredness [7]. Another range of concern could be dependence on the cell phone. Serious cell phone utilize has been related with reliance on the cell phone $[8,9]$. Rationale: Mobile telephones are by and large excessively utilized by teenage, we need to survey the Heatlh risks in restorative understudy by the ued of cell phones they are confronting in everyday life.

\section{Research and Methodology}

a) Study Design: It's a Retro prospective survey based study done in private and government sector of hospital in Karachi.

b) Data Entry: Data entry was done by using SPSS 22 VERSION.

c) Duration of Study: It was a 6 month study starting date from 1 Dec 2016 b to 1 June 2017.

d) Sample Size: we enrolled around 410 all medical students house officers, post graduates and consultants after proper consent, initially sample of 500 peoples, but some data missing so 410 people we enrolled for the study.

e) Location: Private and govt sectors hospital Karachi.

f) Inclusion Criteria: 1. M.B.B.S students, 2. Students, 3. House officer, 4. Post Graduates, 5. Consultant.

g) Exclusion Criteria: Non-medical professions, 2, any disease ear ache, depression.

\section{Result}

In our study we enrolled 410 peoples both male and female from both sectors private and government sectors. Number of people enrolled in our cases our Medical students 246 and post graduates 83,42 house officers and others (consultants, supervisors). The highest usage was in the medical students. The frequency of mobile phone usage is for multiple purposes. Starting from highest to lowest that is social internet 24 percent, SMS for 16 percent, call is 15 percent, for study purpose 12 percent, entertainment (music 11 percent, gaming 9 percent, movie 7 percent) and fashion purpose 6 percent. Facts and figures shown in Figure 1. The frequency of mobile phone usage is for multiple purposes. Starting from highest to lowest that is social internet 24 percent, sms for 16 percent, call is 15 percent, for study purpose 12. percent, entertainment (music 11 percent, gaming 9 percent, movie 7 percent) and fashion purpose 6 percent (Figures $2 \& 3$ ). Number of people enrolled in our cases our Medical students 246 and post graduates 83,42 house officers and others (consultants, supervisors). The highest usage was in the medical students (Figure 4).

\section{Frequency of Phone Use}

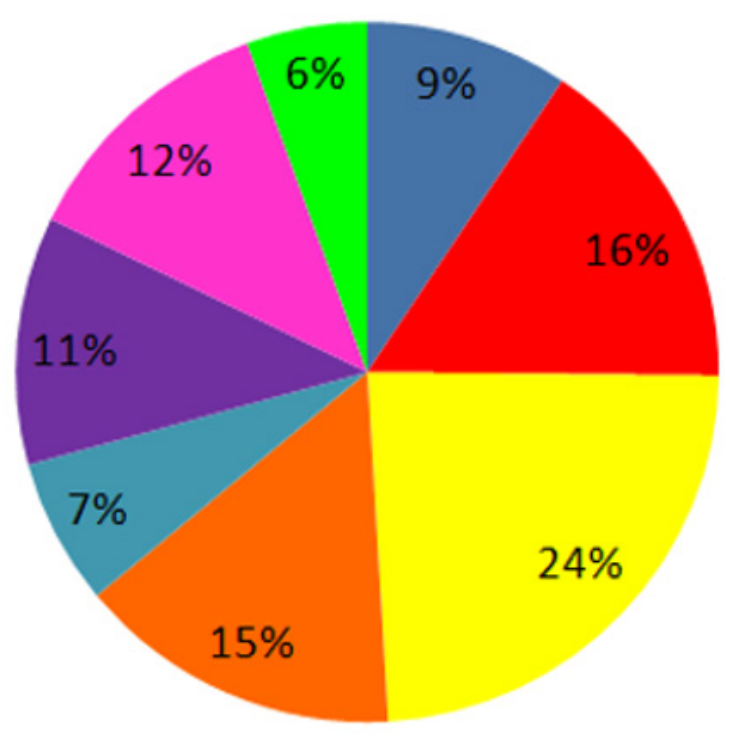

Figure 1. 


\section{Frequency of Symptoms}
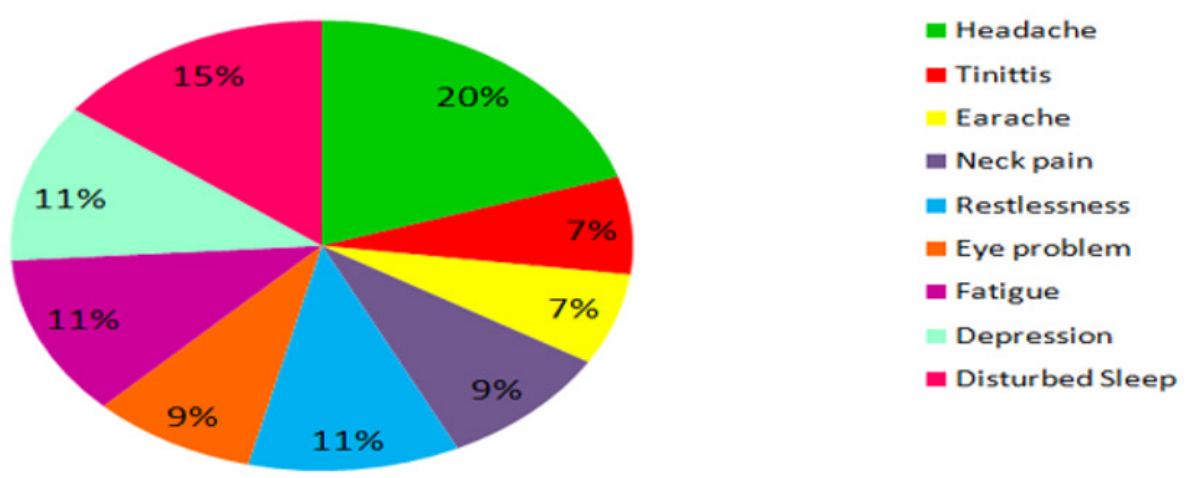

Figure 2.

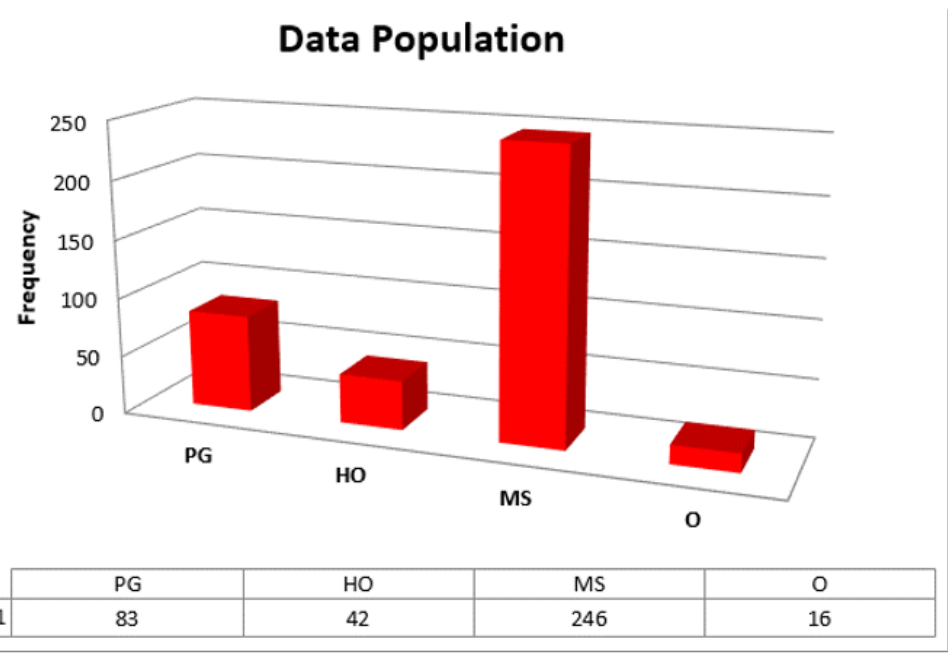

Figure 3.

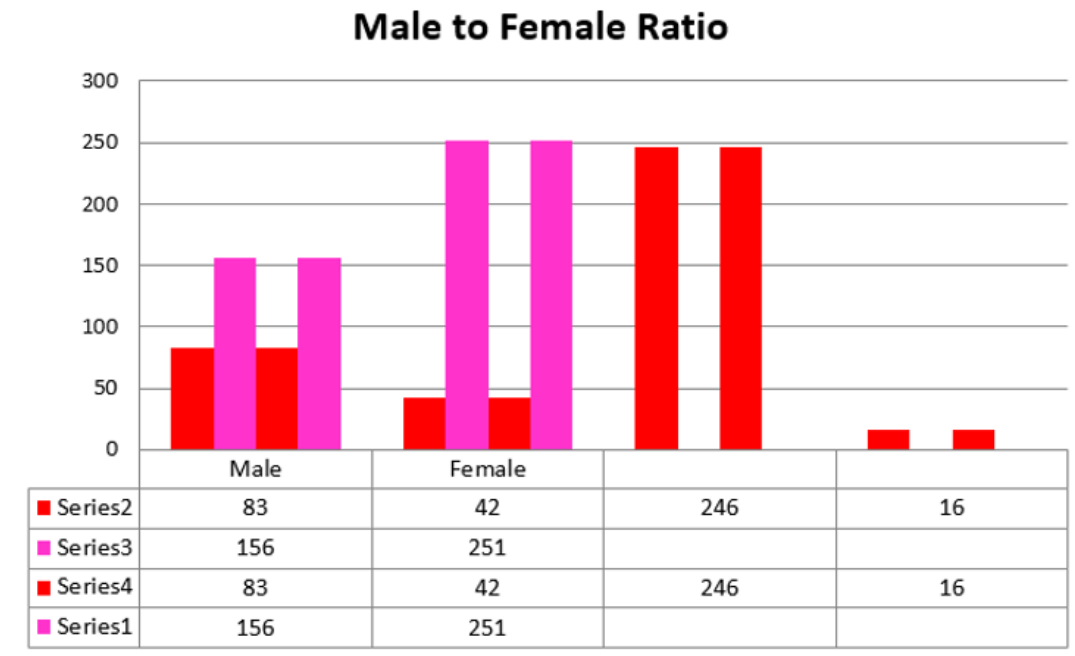

Figure 4. 


\section{Discussion}

Risky cell phone utilize has been a concentration in the writing concerning mental parts of cell phone utilize, where criteria for substance dependence analyze or behavioral addictions $[10,11]$ have been utilized to characterize dangerous utilize [12-18] including enthusiastic short informing administration (SMS) utilize [14]. In this unique circumstance, substantial or issue cell phone utilize (abuse) has been related with physical dissensions, uneasiness, and sleep deprivation [15], misery $[15,18]$, mental trouble [16], and an unfortunate way of life [19]. Be that as it may, conceivable beneficial outcomes of cell phone use on emotional well-being can likewise be theorized, for example the simplicity of contacting somebody to converse with when in need, suggesting access to social support. Social bolster cradles negative impacts of stress [20], while low social support is a hazard consider related with emotional well-being side effects [21].

\section{Conclusion}

Highest percentage of data enrolled were medical students with most frequently use for internet followed by messages and then calling, and most frequent symptoms were headache and disturbed sleep.

\section{Refernces}

1. Ericsson Mobility Report.

2. Levitt, BBlake (1995) Electromagnetic Fields: a consumer's guide to the issues and how to protect ourselves. San Diego: Harcourt Bracep p. 29-38.

3. Eckersley R Commentary on Trzesniewski and Donnellan (2010) A Transdisciplinary Perspective on Young People's Well-Being. Perspectives on Psychological Science 5(1): 76-80.

4. Hunt J, Eisenberg D (2010) Mental health problems and help-seeking behavior among college students. Journal of Adolescent Health 46(1): 3-10.

5. Ming Z, Pietikainen S, Hänninen $O$ (2006) Excessive texting in pathophysiology of first carpometacarpal joint arthritis. Pathophysiology 13(4): 269-270.

6. Gustafsson E, Johnson PW, Hagberg M (2010) Thumb postures and physical loads during mobile phone use - a comparison of young adults with and without musculoskeletal symptoms. Journal of Electromyography and Kinesiology 20(1): 127-135.

7. Punamäki RL, Wallenius M, Nygard CH, Saarni L, Rimpela A (2007) Use of information and communication technology (ICT) and perceived health in adolescence: The role of sleeping habits and waking-time tiredness. Journal of Adolescence 30(4): 569-585.

8. Sánchez-Martínez M, Otero A (2009) Factors associated with cell phone use in adolescents in the community of Madrid (Spain). Cyberpsychology and Behavior 12(2): 131-137.

9. Billieux J, Van der Linden M, D’Acremont M, Ceschi G, Zermatten A (2007) Does impulsivity relate to perceived dependence on and actual use of the mobile phone? Applied Cognitive Psychology 21(4): 527-537.

10. Walsh SP, White KM, Young RM (2008) Over-connected? A qualitative exploration of the relationship between Australian youth and their mobile phones. Journal of Adolescence 31(1): 77-92.

11. Griffiths M (1996) Behavioural addiction: an issue for everybody? Employee Councelling Today. The Journal of Workplace Learning 8(3): 19-25.

12. Bianchi A, Phillips JG (2005) Psychological predictors of problem mobile phone use. Cyberpsychology and Behavior 8(1): 39-51.

13. Takao M, Takahashi S, Kitamura M (2009) Addictive personality and problematic mobile phone use. Cyberpsychology and Behavior 12(5): 501-507.

14. Rutland JB, Sheets T, Young T (2007) Development of a scale to measure problem use of short message service: the SMS problem use diagnostic questionnaire. Cyberpsychology and Behavior 10(6): 841-843.

15. Jenaro C, Flores N, Gómez-Vela M, González-Gil F, Caballo C (2007) Problematic internet and cell-phone use: Psychological, behavioral, and health correlates. Addiction Research and Theory 15(3): 309-320.

16. Beranuy M, Oberst U, Carbonell X, Chamarro A (2009) Problematic Internet and mobile phone use and clinical symptoms in college students: The role of emotional intelligence. Computers in Human Behavior 25(5): 1182-1187.

17. Phillips JG, Butt S, Blaszczynski A (2006) Personality and self-reported use of mobile phones for games. Cyberpsychology and Behavior 9(6): 753758.

18. Yen CF, Tang TC, Yen JY, Lin HC, Huang CF, et al. (2009) Symptoms of problematic cellular phone use, functional impairment and its association with depression among adolescents in Southern Taiwan. Journal of Adolescence 32(4): 863-873.

19. Ezoe S, Toda M, Yoshimura K, Naritomi A, Den R, et al. (2009)Relationships of personality and lifestyle with mobile phone dependence among female nursing students. Social Behavior and Personality 37(2): 231-238.

20. Cohen S (1988) Psychosocial models of the role of social support in the etiology of physical disease. Health psychology 7(3):269-297.

21. Stansfeld S, Candy B (2006)Psychosocial work environment and mental health-a meta-analytic review. Scandinavian Journal of Work Environment and Health 32(6): 443-462. 
This work is licensed under Creative Commons Attribution 4.0 License DOI: 10.19080/JOJPH.2018.03.555624
Your next submission with Juniper Publishers will reach you the below assets

- Quality Editorial service

- Swift Peer Review

- Reprints availability

- E-prints Service

- Manuscript Podcast for convenient understanding

- Global attainment for your research

- Manuscript accessibility in different formats

( Pdf, E-pub, Full Text, Audio)

- Unceasing customer service

Track the below URL for one-step submission https://juniperpublishers.com/online-submission.php 